\title{
Evaluating the longer term benefits of sustainable drainage
}

Richard M. Ashley BSC, MPhil, CEng, MICE

Director, Ecofutures Ltd, Honley, UK; Emeritus Professor, Pennine Water

Group, University of Sheffield, Sheffield, UK (corresponding author:

r.ashley@sheffield.ac.uk)

Christopher J. Digman BEng, PhD, CEng, FICE

Technical Director, MWH now part of Stantec, Wakefield, UK

Visiting Professor, University of Sheffield, Sheffield, UK

Bruce Horton MA, PhD, CEnv

Principal Environmental Economist, MWH, Wakefield, UK

\section{Berry Gersonius PhD}

Senior Lecturer, Unesco-IHE Institute for Water Education, Delft

Netherlands
Brian Smith BSC, CEng, MICE, MCIWEM

Sewerage Optimisation Manager, Yorkshire Water, Bradford, UK

Paul Shaffer BSc (Hons)

Research Manager, Ciria, London, UK

Adam Baylis MA (Cantab)

Principal Scientist, Environment Agency, Bristol, UK

Sustainable drainage systems (SuDS) can bring a wide range of benefits in addition to reductions in flood risk. However, there is limited quantified evidence of the value of these benefits. To help address this, the Construction Industry Research and Information Association led a project to develop the Benefits of SuDS Tool (Best). The approach presented in this paper shows how scenario planning can be used in Best to evaluate longer term benefits in the face of future uncertainty. Three case studies are presented, showing how this can inform robust decisions and the selection of SuDS options for maximum value.

\section{Introduction}

In addition to ensuring primary functionality, maximising overall value is an important goal in infrastructure design. Until recently, accounting procedures have struggled to allow effective inclusion of broader environmental and social impacts (e.g. Obst et al., 2016). The millennium ecosystem assessment (MEA) provides a broad set of internationally agreed defined benefits from ecosystem services (ESS) (e.g. Sukhdev et al., 2010). Monetisation of individual ESS components to demonstrate value is changing the way in which infrastructure options are selected.

In managing urban area drainage, 'burying the problem' of surface water is gradually being replaced by an approach that utilises the opportunities provided by rainfall where it lands (Woods Ballard et al., 2015). What was formerly seen as 'sustainable development' (e.g. Allen et al., 2016) is aligning to the 'circular economy' - a subtle shift that puts economics at the heart of the decision process (e.g. EEA, 2016). This reflects an increasing need for the impacts of decisions to be explicit and for investments to deliver value for money.

Sustainable drainage systems (SuDS) comprise a range of measures, as defined in the Construction Industry Research and Information Association (Ciria) 'SuDS manual' (Woods Ballard et al., 2015), that provide a wide range of benefits (Figure 1). Traditional piped drainage systems and many below-ground $\mathrm{SuDS}$ deal with the quantity and, to some extent, the quality aspects of stormwater runoff, but provide no added benefits. The benefits from SuDS include those illustrated in Table 1 (see also Jayasooriya and $\mathrm{Ng}, 2014$ ). Many of these benefits can be understood from the MEA ESS accounting guidance and other guidance for social or health benefit accounting, as explained by Social Value UK (2012) and WHO (2016), respectively.

A number of tools and procedures can assess the wider benefits of SuDS, but few provide a monetised result. Hoang et al. (2016) develop a means to assess 'spatially distributed benefits intensity', which is considered to be context and location specific. In the USA, the Center for Neighborhood Technology (CNT, 2010) monetisation tool is used for SuDS (termed green infrastructure (Fletcher et al., 2015)) while, in the Netherlands, the Teeb urban tool has been developed for valuing blue-green infrastructure (BGI) (Van Dijk et al., 2013).

In a UK project managed by Ciria, the freely available tool Best (Benefits of SuDS Tool) was developed for valuing the benefits of SuDS (Ciria, 2016). Best is now being used for scenario planning, following a similar approach as used for flood and coastal erosion risk management in the UK (Brisley et al., 2015).

The traditional approach to evaluate the effectiveness of design options usually considers the status quo (i.e. current environmental and societal factors) and then provides an allowance for future changes, such as factoring rainfall by some $30 \%$ and increasing paved areas from development plans with an allowance for urban creep. In Best, this approach is termed 'business-as-usual' (BaU). By selecting one value for rainfall uplifts and another for increases in drained areas, BaU assumes a single version of what the future will be like (the BaU scenario). The third edition of Best Ciria (2016) includes 


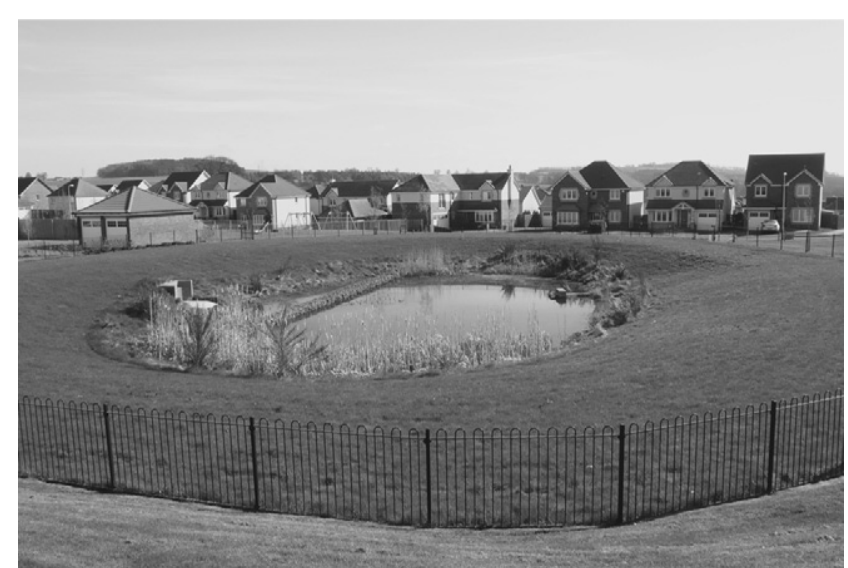

Figure 1. Illustration of a blue-green SuDS system in Dundee, Scotland (Photograph Richard Ashley)

the means to evaluate benefits under multiple scenarios (visions of future states) in addition to $\mathrm{BaU}$.

This paper presents findings from the use of Best for two case studies in the UK and one in the Netherlands. These are used to show how the individual benefits vary between options and over time and to highlight the importance of considering the longer term in assessing the financial and other benefits of SuDS, especially for planning for adaptability and flexibility when managing system resilience. There are important questions regarding how to reconcile the value to the main beneficiaries from the use of SuDS and BGI with those who fund these systems now and in the future, and also how to get the most value from SuDS and avoid the 'market failure' of not exploiting them (Ciwem, 2017).

\section{The benefits of blue and green SuDS}

SuDS comprise a range of features and invariably include sections of piped drainage. Of the many benefits that SuDS can potentially provide (e.g. Table 1), certain measures will be more effective than others at providing the benefits, which are time and context dependent. For example, where SuDS replace existing blue or green spaces, the relative magnitude of any added benefits will be significantly less than in situations where SuDS replace paved areas (e.g. Hoang et al., 2016; Ossa-Moreno et al., 2017). In addition, not all 'SuDS' are the same when considering their potential benefits. Certain SuDS are comprised entirely of BGI, but may have inlet and outlet features using pipes and concrete. Other SuDS do not include blue or green measures. The case studies presented in this paper are for SuDS that utilise BGI.

The development of Best included a review of existing valuation tools and over 500 monetary values from more than 100 valuation studies of potential relevance to SuDS in the UK (Ciria, 2013). While many of these studies and values were not appropriate for inclusion, the review produced a dataset of relevant and potentially transferable values covering each benefit category and a variety of different contexts (Ciria, 2015). The approach to assessing the benefits uses an impact pathway approach (Defra, 2011), which links SuDS components to impacts on human welfare, as illustrated in Figure 2 for air quality. Monetary valuation of benefits in Best is based on a range of market and non-market approaches using available evidence, including the value transfer approach in UK flood and coastal erosion risk management assessments (Eftec, 2009). Table 1 shows the valuation approaches used for each of the benefit categories in Best (Ciria, 2013). Details of the way in which each of the benefits is assessed in monetary or qualitative terms are given in technical guidance for the tool (Ciria, 2016).

\section{Case study examples using Best}

Experience from applying Best to three case studies is used to illustrate the implications of valuing the benefits. An outline of the proposed developments in Roundhay Park (Leeds, UK), Killingworth and Long Benton (Northumbria, UK) and

Table 1. Benefits and outline of the approach used for their valuation in Best

$\begin{array}{lll}\text { Benefit category } & \text { Valuation approach } & \text { Units } \\ \text { Air quality } & \text { Damage cost } & \mathrm{f} / \mathrm{t} \text { pollutant } \\ \text { Amenity } & \text { Value transfer (hedonic) } & \text { Percentage house price change } \\ \text { Biodiversity and ecology } & \text { Value transfer } & \mathrm{f} / \mathrm{ha} \\ \text { Building temperature } & \text { Long-run variable cost } & \mathrm{f} \text { energy saved } \\ \text { Carbon reduction and sequestration } & \text { Marginal abatement cost } & \mathrm{f} / \mathrm{t} \\ \text { Education } & \text { Avoided investment } & \mathrm{f} / \mathrm{school} \mathrm{trip} \\ \text { Flood risk reduction } & \text { Damage cost } & \mathrm{f} / \mathrm{property} \\ \text { Groundwater recharge } & \text { Avoided abstraction cost } & \mathrm{f} / \mathrm{m}^{3} \\ \text { Health } & \text { Avoided health costs } & \mathrm{f} / \mathrm{person} \\ \text { Pumping wastewater } & \text { Long-run variable cost } & \mathrm{f} \text { energy saved } \\ \text { Rainwater harvesting } & \text { Avoided investment } & \mathrm{f} / \mathrm{m}^{3} \\ \text { Recreation } & \text { Value transfer (travel cost) } & \mathrm{f} / \mathrm{visit} \\ \text { Treating wastewater } & \text { Avoided treatment cost } & \mathrm{f} / \mathrm{m}^{3} \\ \text { Water quality } & \text { Value transfer (stated preference) } & \mathrm{f} / \mathrm{km}\end{array}$




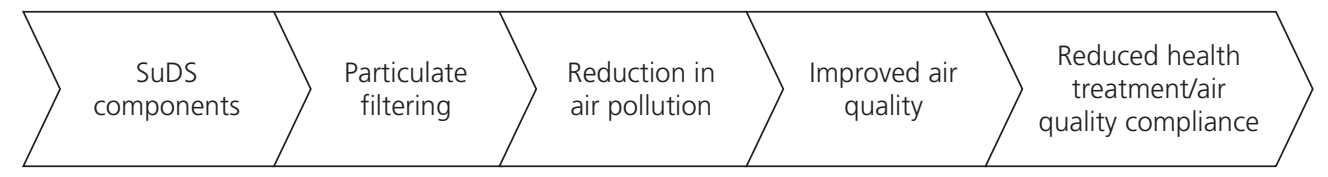

Figure 2. Illustration of the impact pathway approach for air quality and impact on health

Dordrecht (the Netherlands) are set out in Table 2, together with the options considered for each case. In each case, flood risk reduction is either the main objective or a significant consideration. However, each case has unique considerations, including the periods of analysis and start and end dates for their functioning. This paper only sets out to illustrate aspects of benefit valuation using Best and therefore does not show all of the results for Best analytical processes for every case study. Details of the analyses of the two UK cases studies are given elsewhere (Ciria, 2017). The full results of the Dordrecht case study will be published once the analysis comparing Best with Teeb is complete.

\subsection{Results under traditional BaU analysis}

Figure 3 shows a comparison of costs and benefits for $\mathrm{BaU}$ evaluated using Best for the four options considered for the Roundhay Park case study (as summarised in Table 2) for the client-defined period 2015-2095. The use of conventional tanks (option 1) reduces combined sewer overflow (CSO) spills but offers no other benefits. Option 2 (tanks plus additional

Table 2. Characteristics of Best case studies

\begin{tabular}{|c|c|c|}
\hline Catchment information & $\begin{array}{l}\text { Primary objective of } \\
\text { the scheme }\end{array}$ & Options considered \\
\hline \multicolumn{3}{|l|}{ Roundhay Park, UK } \\
\hline \multirow{4}{*}{$\begin{array}{l}\text { This catchment has current water quality problems from } \\
\text { the CSOs and also periodic flooding including of } \\
\text { properties. Population 4700; } 46 \text { ha contributing area. } \\
\text { Mixed dense and open urban and existing park areas }\end{array}$} & \multirow{4}{*}{$\begin{array}{l}\text { To improve habitats for } \\
\text { white-clawed crayfish }\end{array}$} & 1. CSO tanks \\
\hline & & 2. As above with additional storage \\
\hline & & 3. SuDS in public spaces \\
\hline & & 4. SuDS in public and private spaces \\
\hline \multicolumn{3}{|l|}{ Killingworth and Long Benton, UK } \\
\hline $\begin{array}{l}\text { The catchment has periodic flooding problems even with } \\
\text { relatively modest rainfall events. } 20400 \text { properties, with }\end{array}$ & \multirow[t]{3}{*}{ To reduce flood risks } & $\begin{array}{l}\text { 1. SuDS to provide attenuation and surface water } \\
\text { conveyance with exceedance storage }\end{array}$ \\
\hline a population of 39600 and a contributing area of & & 2. As above plus flood protection for an additional \\
\hline $\begin{array}{l}1500 \text { ha. The catchment is semi-rural and there is a lot of } \\
\text { space for potential SuDS }\end{array}$ & & 749 properties \\
\hline \multicolumn{3}{|l|}{ Dordrecht, the Netherlands } \\
\hline $\begin{array}{l}\text { Area } 135 \text { ha, with } 4 \text { ha (3\%) of open water and } 40 \text { ha } \\
(30 \%) \text { of paved area, drained by a combined sewer } \\
\text { system. Flooding is a risk for short return period events of } \\
\text { around } 10 \text { years }\end{array}$ & $\begin{array}{l}\text { Urban regeneration to } \\
\text { improve liveability }\end{array}$ & $\begin{array}{l}\text { Plan is to fit } 5000 \mathrm{~m}^{2} \text { of new green-blue area with } \\
260 \text { new trees at the same time as regenerating } \\
\text { urban neighbourhoods }\end{array}$ \\
\hline
\end{tabular}

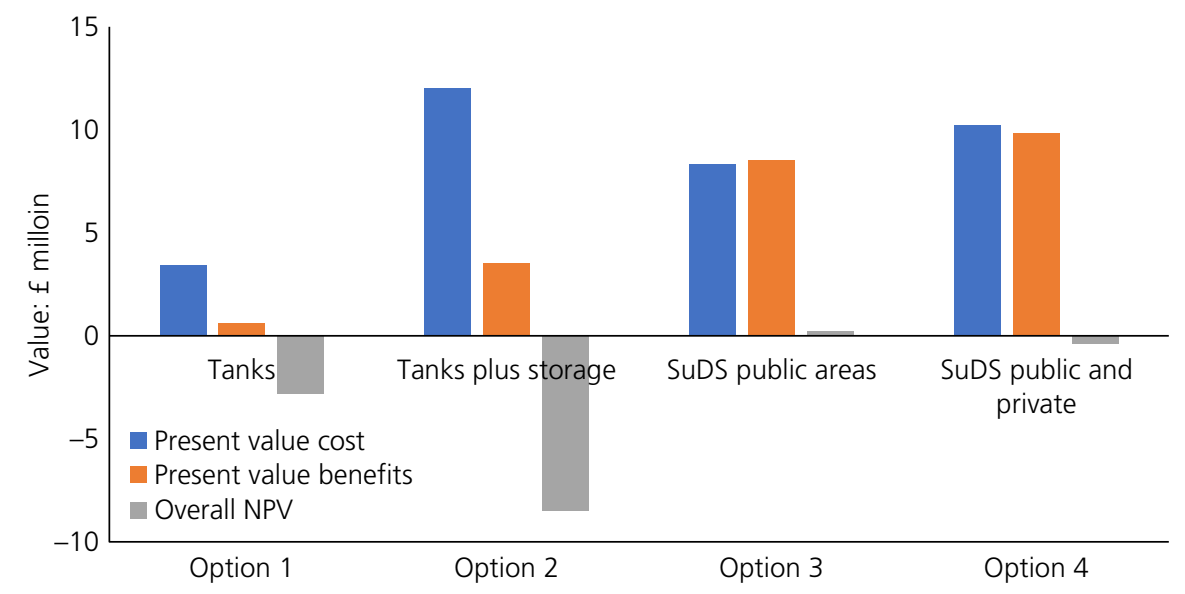

Figure 3. BaU results from Best for the Roundhay Park case study for each option considered 
flood measures) provides similar levels of water quality and flood risk reduction performance as options 3 and 4, but fewer benefits, with a performance that meets the required standard for numbers and volumes of CSO spills and flooding, similarly to that provided by SuDS in public areas (option 3) or SuDS in public and private areas (option 4). Both options 3 and 4 create a second surface-based drainage network and bring wider benefits, but add costs. However, to deliver and sustain the SuDS would necessitate public engagement and private responsibility, with considerable risks that these systems would not be maintained. The distribution of the main benefits for the only option with a positive net present value (NPV) SuDS in public places (option 3) - is shown in Figure 4. This figure reveals that, although the objective is to enhance water quality, the main benefits are for amenity and flood risk reduction. Most of the amenity benefit is reflected in property values that accrue mainly to the property owners. The technical guidance for Best (Ciria, 2016) explains how this benefit is valued from data obtained from 'willingness-to-pay' or 'hedonic pricing' studies, which model the impact on property or land values from enhancements to the local environment. There are also risks that there are overlaps between amenity as defined and valued in Best and other monetised benefits (especially recreation, biodiversity or water quality), and the guidance stresses the need to avoid double counting in this context (see also Ossa-Moreno et al., 2017).

Option 3 has a positive NPV, but the relative costs are some 2.5 times those of the conventional solution (option 1). This leaves decision makers with a difficult choice - to spend significantly more money to get additional benefits for society as a whole or to spend the minimum and achieve regulatory compliance, but not maximise the overall benefit to society.

Comparisons of the two options considered for the Killingworth and Long Benton case study (Table 2) are shown in Figure 5 for BaU. Both options demonstrate a significant positive net benefit over the client-defined 2017-2117 timescale

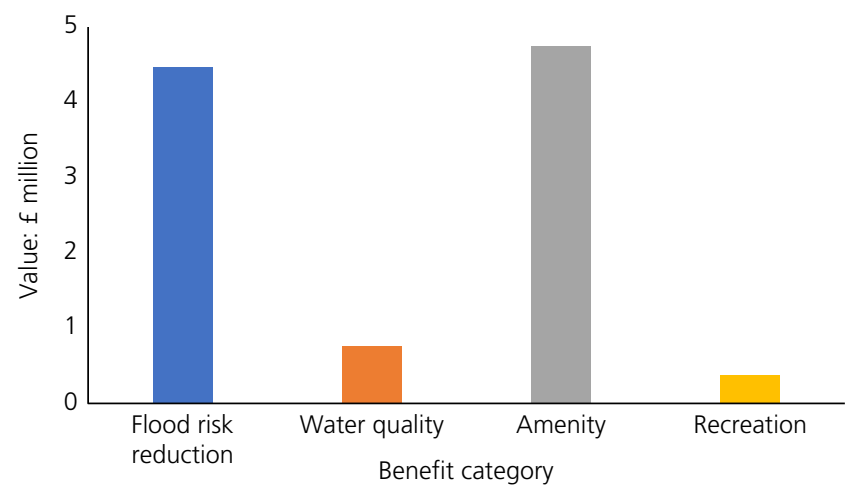

Figure 4. Distribution of benefits for SuDS option 3 for Roundhay Park BaU

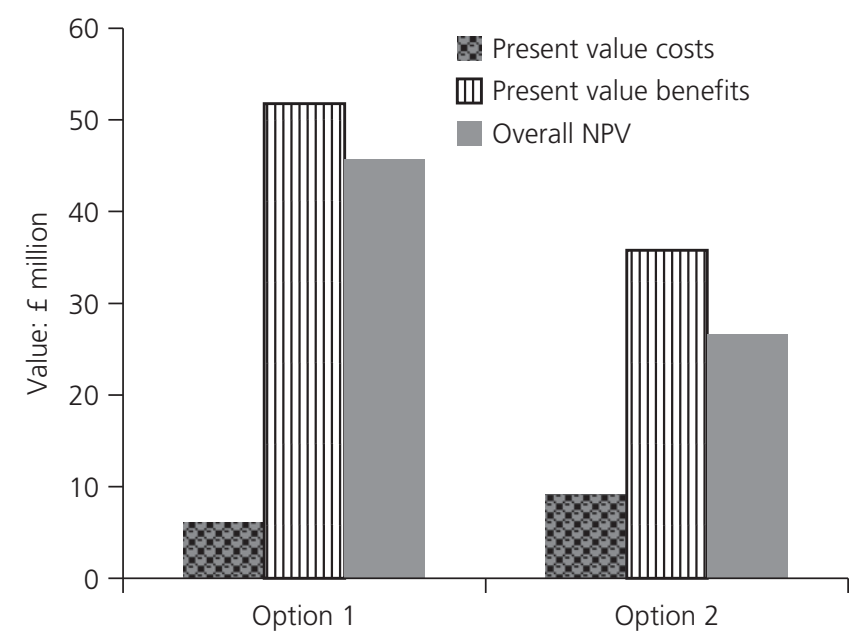

Figure 5. Overall benefit results for the Killingworth and Long Benton case study obtained using Best

of analysis. Table 3 shows a breakdown of the main benefits for option 1. In this case, the main benefits arise due to flood risk reduction with lesser value from water quality improvements and recreation. There is no large increase in amenity benefits, as was found in the Roundhay Park case. This is because the portfolio of SuDS for Killingworth and Long Benton does not add to the amenity as development is on land where there are already blue and green spaces.

Best and Teeb were both used to estimate the benefits of a proposed BGI retrofit scheme in the city of Dordrecht. The plan for the retrofit scheme is to open up the centre of the neighbourhood for blue and green space (Table 2). The breakdown of the main benefits assessed using Best and Teeb (discounted over 30 years) is given in Table 4 for $\mathrm{BaU}$. The relative distribution of benefits is similar for both the Best and Teeb tools, despite the benefit categories differing and albeit with overlaps. In both tools, the dominant benefits relate to amenity because the properties involved will be overlooking a local park instead of a busy road. Each tool also assigns value to health benefits as the next greatest impact. Although the tools are not directly comparable (Esquivel Gómez, 2016), these results indicate similarities in the assignment and distribution of benefits in the Dordrecht case study.

Table 3. Distribution of the main benefits for Killingworth and Long Benton option 1 determined using Best

\begin{tabular}{|lr|}
\hline Benefit & \multicolumn{1}{c|}{ Value: $\mathbf{f}$} \\
\hline Flood risk reduction & 49835955 \\
Water quality improvements & 1435055 \\
Recreation & 312375 \\
Amenity & 100292 \\
Education & 65943 \\
Biodiversity and ecology & 38956
\end{tabular}


Table 4. Results for Dordrecht retrofit of SuDS from use of Best and Teeb valuation tools

\begin{tabular}{|llrc|} 
Benefit category & Tool & \multicolumn{1}{c}{ Value: $€$} & $\begin{array}{c}\text { Proportion of total } \\
\text { benefit: \% }\end{array}$ \\
\hline Amenity & Best & 9853440 & 77 \\
Price of properties & Teeb & 10706211 & 94 \\
Health & Best & 3041908 & 22 \\
Health & Teeb & 221923 & 2 \\
Air quality & Best & 41868 & $<1$ \\
Energy & Teeb & 189745 & 2 \\
& & & \\
\end{tabular}

So far, only the traditional BaU scenario (i.e. today's situation plus one future projection) has been considered for each case study. The next section outlines the approach used in Best to include alternative futures using scenario planning.

\subsection{Looking to the future}

There is no definitive prediction of what the future needs, challenges or opportunities might be for the proposed options to address, despite the $\mathrm{BaU}$ assumptions above. There is thus significant uncertainty about the future performance and effectiveness of schemes designed today. A robust option is one that is less sensitive to the possible changes that may come about over time (Casal-Campos et al., 2015). Next to aspiring for robustness, uncertainty about the future may require the system/option to be adapted or modified over time; therefore flexibility is an aspirational system characteristic. Best utilises the modified Cofas tool (Eckart et al., 2012) to estimate the relative distribution of benefits from SuDS as a surrogate for flexibility as an indication of the relative distribution of benefits for each option and therefore their potential for providing benefits under possible futures (Ciria, 2016). This method provides a score to indicate the distribution of the various benefits for an option. A five-band scale is used (band A, $81-100 \%$; B, $61-80 \%$; C, $41-60 \%$; D, 21-60\% and E, $0-20 \%$ ). In this scale, $100 \%$ is where there are a number of benefits, each of similar magnitude; an option with only one significant benefit accrues a score of $0 \%$. Scores between 0 and $100 \%$ show that there are various benefits, but the benefits differ in magnitude.

The third edition of Best (Ciria, 2016) also includes scenario planning (Maier et al., 2016) to help users consider the performance of options under plausible futures rather than the single future assumed in the $\mathrm{BaU}$ analysis. This corresponds with the standard Environment Agency approach used for flood and coastal erosion risk management planning (Brisley et al., 2015). In Best, a three-step approach determines the relative robustness of the various options. Robustness provides the decision maker with information as to the likelihood of the option functioning in the future, whatever that future may look like. Step 1 is the BaU described in Section 3.1. In step 2 there are three optional levels of analysis to ensure proportionality of analysis depending upon the scale of the development. These levels are

- level 1, for small-scale SuDS and initial screening of larger developments

- level 2, for intermediate-scale SuDS

- level 3, for the largest scale and most complex of SuDS schemes.

In step 2, the level 1 analysis screens out the least robust options and is therefore always worth undertaking to reduce the number of options considered in detail in level 2 or level 3 analysis. The analysis utilises up to four socio-economic scenarios as explained below. In step 3, the results are reviewed for decision-making.

Scenario analysis was undertaken for both the Roundhay Park and Killingworth and Long Benton case studies. Scenario analysis has not yet been undertaken for the Dordrecht scheme. Four scenarios were used in the UK case studies (see the Supplementary Material to this paper for further details). These scenarios are world markets (WM), national enterprise (NE), global sustainability (GS) and local stewardship (LS), defined in the Foresight programme together with climate predictions (UKCIP, 2000). Following a definition of the important drivers, impacts and potential consequences for each scenario by the stakeholder group (Table 5), these were used to assess the robustness qualitatively of all options against each scenario. In Best, a value of 1 is assigned to an option considered robust under a particular scenario and time epoch, and a value of 0 is assigned where the option is not considered robust; half scores are also possible where there is less certainty. Hence, where there are four scenarios, each option may score between 0 and 4 , with increments of $0 \cdot 5$.

In the Roundhay Park case, option 1 (CSO tanks) scored 1.5 and option 3 (SuDS in public areas) scored 3.5. The level 2 simple method was applied as this requires no additional reruns of the physical models (that create inputs for Best), unlike a level 3 analysis. An analysis of flexibility showed that option 1 scored as band E, whereas option 3 scored up to a maximum of band $\mathrm{D}$ depending on the scenario and the time period (epoch) considered. The stakeholder group defined these epochs as periods over which the SuDS would function without major interventions: 2015-2030, 2015-2055 and 20152095. Only option 3 (SuDS in public areas) was considered in the further analysis.

Figure 6 shows the distribution of the main monetary benefits for SuDS option 3 for Roundhay Park for the three consecutive epochs determined using Best and applying user-defined weighting scores $(0,25, \ldots, 175,200 \%)$ to the individual benefits determined under $\mathrm{BaU}$ for each scenario and for each epoch. Between 2015 and 2030 the rate of change was modest and hence scenario analysis was not considered (Figure 6(a)). 
Table 5. Examples of drivers and consequences under the four socio-economic scenarios for Roundhay Park case study 40 years after construction (2055) (this analysis was undertaken prior to the vote to leave the EU)

\begin{tabular}{|c|c|c|c|c|}
\hline \multirow[b]{2}{*}{ Driver } & \multicolumn{4}{|c|}{ Consequences } \\
\hline & $\begin{array}{l}\text { WM scenario (high } \\
\text { climate change) }\end{array}$ & $\begin{array}{l}\text { NE scenario (medium } \\
\text { climate change) }\end{array}$ & $\begin{array}{l}\text { GS scenario (low } \\
\text { climate change) }\end{array}$ & $\begin{array}{l}\text { LS scenario (low-medium } \\
\text { climate change) }\end{array}$ \\
\hline $\begin{array}{l}\text { National planning } \\
\text { requirements; green } \\
\text { infrastructure strategy } \\
\text { and so on }\end{array}$ & $\begin{array}{l}\text { Relaxed regulations, mix } \\
\text { of land use types, less } \\
\text { local industry }\end{array}$ & $\begin{array}{l}\text { Highly regulated planning, } \\
\text { but environment less } \\
\text { important; no longer in EU; } \\
\text { local (national) regulations }\end{array}$ & $\begin{array}{l}\text { Strong controls, denser } \\
\text { communities }\end{array}$ & $\begin{array}{l}\text { Low (national), high local; } \\
\text { simpler lifestyles and } \\
\text { lower costs; leave EU }\end{array}$ \\
\hline Government priorities & Economic growth & $\begin{array}{l}\text { Government specifying } \\
\text { regulations, not the EU }\end{array}$ & $\begin{array}{l}\text { Strong controls to } \\
\text { sustain planet. } \\
\text { Circular and } \\
\text { sustainable approach }\end{array}$ & $\begin{array}{l}\text { More decentralised } \\
\text { (e.g. devolved Yorkshire). } \\
\text { London less important }\end{array}$ \\
\hline $\begin{array}{l}\text { Regulation in water } \\
\text { sector }\end{array}$ & $\begin{array}{l}\text { Relaxed regulations, mix } \\
\text { of land use types, less } \\
\text { local industry }\end{array}$ & $\begin{array}{l}\text { Less international, more } \\
\text { national regulation; } \\
\text { leave EU }\end{array}$ & $\begin{array}{l}\text { Strong regulation, } \\
\text { possible } \\
\text { nationalisation of } \\
\text { industry }\end{array}$ & $\begin{array}{l}\text { Leave EU, but locally } \\
\text { decided with local services }\end{array}$ \\
\hline $\begin{array}{l}\text { Rainfall-runoff-urban } \\
\text { growth, more surface } \\
\text { water }\end{array}$ & $\begin{array}{l}\text { High climate change } \\
\text { and rainfall - only } \\
\text { richest in society } \\
\text { properly protected }\end{array}$ & $\begin{array}{l}\text { More catchment } \\
\text { management planning and } \\
\text { maintenance of sewers }\end{array}$ & $\begin{array}{l}\text { Reduced flooding with } \\
\text { lower impacts - adapt } \\
\text { and mitigate }\end{array}$ & $\begin{array}{l}\text { Wide and varied range - } \\
\text { overall society more } \\
\text { resilient }\end{array}$ \\
\hline $\begin{array}{l}\text { Expectations and } \\
\text { behaviours }\end{array}$ & $\begin{array}{l}\text { High expectations in } \\
\text { wealthiest areas }\end{array}$ & $\begin{array}{l}\text { High among public, but } \\
\text { expect government to pay. } \\
\text { Low taxes }\end{array}$ & $\begin{array}{l}\text { Expect high standards } \\
\text { with government } \\
\text { control. Circular } \\
\text { economy }\end{array}$ & $\begin{array}{l}\text { Less ownership of goods; } \\
\text { lower aspirations and } \\
\text { more willingness to } \\
\text { behave responsibly }\end{array}$ \\
\hline
\end{tabular}

There are four significant benefits, with amenity being the greatest (as in the BaU case). From 2030 to 2055 (Figure 6(b)) and 2055 to 2095 (Figure 6(c)), flood risk reduction and other benefits dominate but the distribution is different for each scenario. The benefits were determined by weightings based on stakeholder scoring (detailed earlier) as to how the values may change after 2030 and up to 2055 and then from 2055 to 2095 . For example, in each case the relative value of the benefits from flood risk reduction were sustained and weightings of $100 \%$ (i.e. the same as under $\mathrm{BaU}$ ) were given under each scenario and for each time period, whereas recreational benefits were weighted as increasing in value $(125 \%)$ only for the LS scenario for 2030-2050; for 2055-2095, they were weighted (compared with $\mathrm{BaU}$ ) as $150 \%$ (WM), 50\% (NE), 100\% (GS) and $150 \%$ (LS). In both the robustness analysis and the weighting processes, subjective allocations of scores were made by the stakeholders in discussion. Therefore, these may not give precise results and there remain significant uncertainties that could be considered further in a sensitivity analysis. However, this is only recommended for the more detailed level 3 scale of a project.

Flood risk reduction remains the most significant benefit provided for the two time periods beyond 2030 and for each scenario. The uniformity of the value of the flood risk reduction benefits across all scenarios shows that these benefits are likely to be robust whatever the future. The amenity benefits cease from the second period for all scenarios because of the one-off nature of the property value increase. This corresponds with the findings of Zhou et al. (2013) regarding increased property values from BGI levelling off over time. From this analysis, SuDS in public areas (option 3) was found to be the more robust and the most flexible (most uniform distribution of benefits) option and to provide a range of individual benefits, as well as the primary objective of water quality improvement, that are sustained (apart from the amenity benefits) over the three epochs considered.

Overall, the BaU analysis determined the total benefits to be $£ 11 \cdot 1$ million for SuDS in public areas (option 3). Summing the values for the three time epochs in Figures 6(a)-6(c), the present values of the benefits using a UK government discount rate of $3.5 \%$ were found to be $£ 10.6$ million, $£ 10.0$ million, $£ 9.4$ million and $£ 10 \cdot 8$ million for WM, NE, GS and LS scenarios, respectively. A small reduction in benefit value over time was found for each scenario, but this is not significant in terms of the overall uncertainty in the analysis. The distribution of benefits for each scenario varies for each epoch but never scores higher than band $\mathrm{D}$, a relatively poor distribution of benefits in the longer term. This is because a single benefit (flood risk reduction) dominates the overall value.

A Best scenario analysis for Killingworth and Long Benton used the level 2 analysis to determine the way in which the benefits for option 1 may change over time (Figure 7). This shows how the benefits change between scenarios and for the stakeholder-defined three sequential time epochs considered. In each case the dominant benefit was from flood risk reduction, which remained the most significant benefit over time and in each of the scenarios. The changes in value for the 


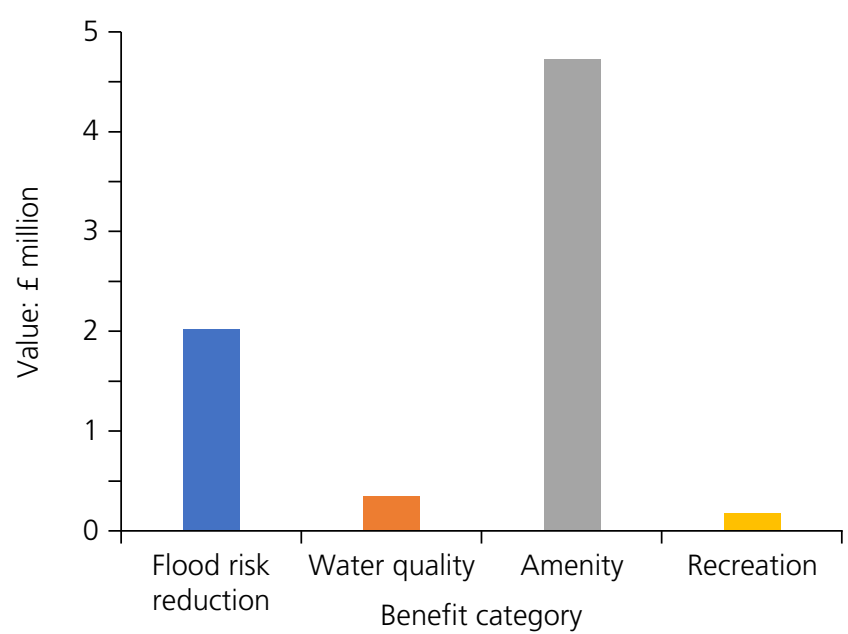

(a)

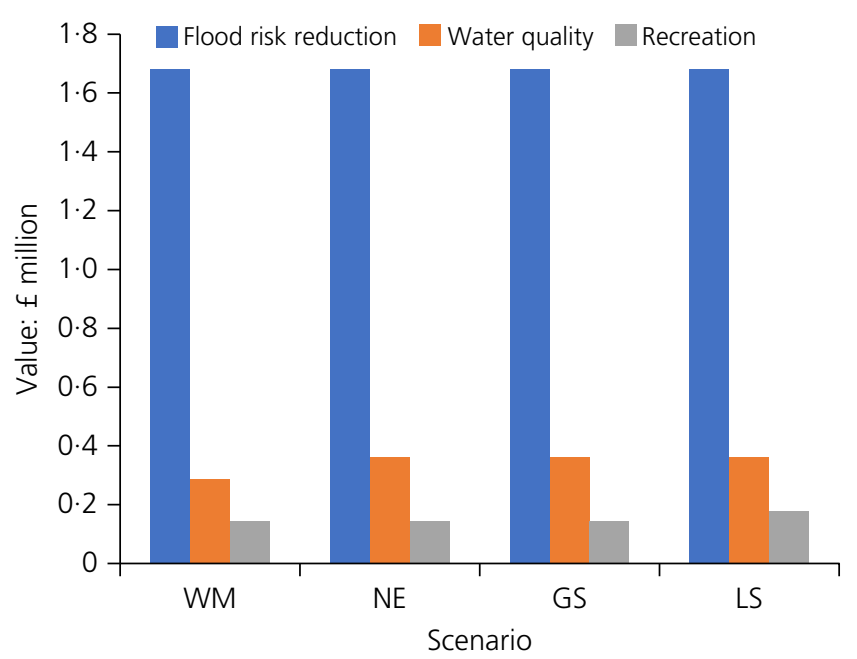

(b)

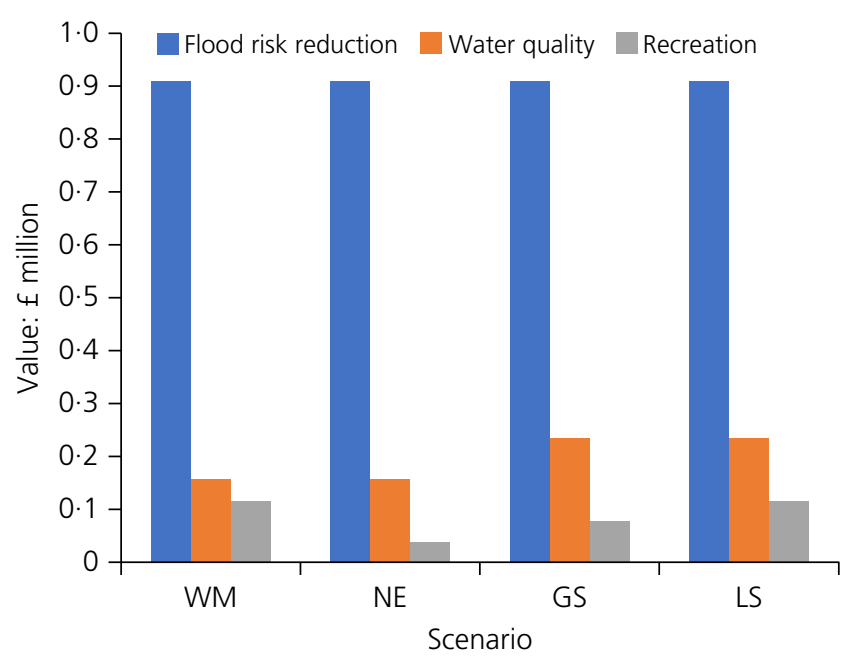

(c)

Figure 6. Benefits of option 3 for Roundhay Park determined using Best for three epochs under four scenarios: (a) 2015-2030; (b) 2030-2055; (c) 2055-2095

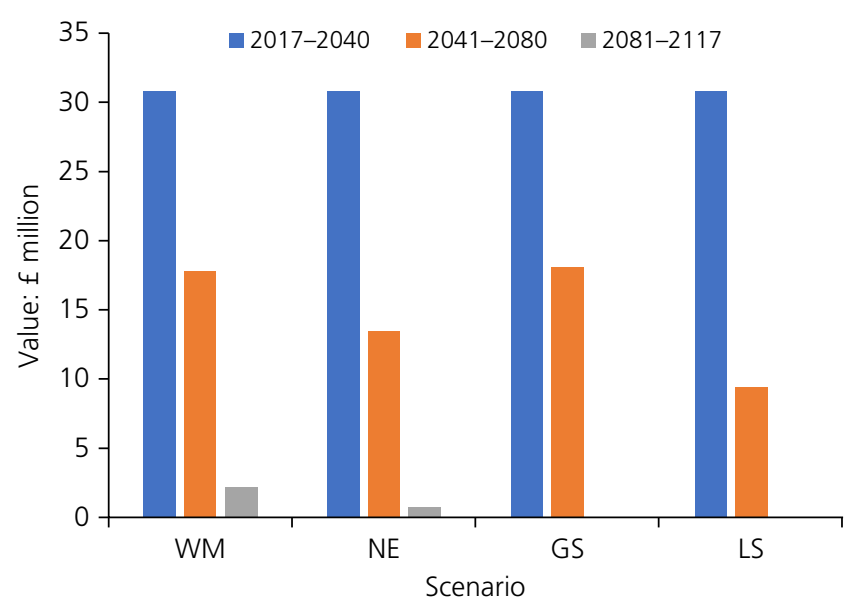

Figure 7. Best scenario analysis results for Killingworth and Long Benton for three time epochs (2017-2040, 2041-2080 and 2081-2117) and for the four scenarios used in Figure 6

second and third epochs used the scaling of the benefits from stakeholder-assigned weightings in the same way as for the Roundhay Park case study. In each scenario, the distribution of benefits scored was in the lowest category (band E). This is because the benefits are dominated by flood risk reduction, the primary objective of the scheme; hence option 1 lacks flexibility but provides the required performance.

Further or more detailed scenario analysis can be carried out by re-running the physical models for the proposed options in each case study (i.e. a level 3 analysis above). These runs would need to utilise the changes to systems, drivers and future conditions defined by the scenarios and for each epoch. It is recommended that this be done only for larger or more significant schemes due to the cost of such analysis.

The final step 3 of the analysis is where the outcomes are reviewed and the preferred option is selected. This decision is informed by all of the results from the analyses conducted.

The case study analyses have illustrated how, despite each case having a primary objective, each scheme where SuDS are used can deliver a number of other benefits, in some cases of greater magnitude than those provided by the primary objective. The SuDS option for Roundhay Park, with water quality improvements as the main objective, in fact delivers greater benefits from amenity and flood risk reduction, whereas the Killingworth and Long Benton SuDS option, which aims at flood risk reduction, does deliver the greatest benefits for this. In Dordrecht, the primary objective is regeneration to improve liveability. However, the greatest benefits identified using both Best and Teeb were property values (amenity) and health.

\subsection{Leveraging value}

Throughout the analysis process outlined in the previous sections, ways in which added value from the SuDS options can 
be obtained should be considered, including who the stakeholders are now and who they may be in the future and whether or not added benefits can be achieved by making relatively minor additional investments. Adding significant value from marginal investments is termed 'leveraging' (Abson et al., 2016) in Best analysis, and this is illustrated for the Roundhay Park case study in the Supplementary Material to this paper. This shows that, by increasing the numbers of trees from the original 250 to 1000 , the number of people with a view over green spaces increases from 125 to 500 and the health benefits rise from $£ 0.6$ million to some $£ 3.3$ million for a limited additional cost of around $£ 0 \cdot 25$ million.

\section{The challenges of taking advantage of the benefits on offer}

Given that society is the main recipient of the multiple benefits, how do the current arrangements for surface water management in England and Wales (Ellis and Lundy, 2016) encourage or inhibit the delivery of SuDS benefits and how might this be improved? Ellis and Lundy (2016) show that if the multiple benefits from SuDS are to be fully realised there are considerable complexities in trying to work across the numerous interested parties and sectors, many of whom overlap in jurisdictions.

In Philadelphia, the mayor has jurisdiction over all of the major services of the city. The mayor's purview includes all of the benefits addressed in Best and more. The tool developed by CNT (2010) has been used to show that the overall value of using SuDS to manage $50 \%$ of the CSO spills in Philadelphia is some $\$ 2.6$ billion, compared with only about $\$ 100$ million in benefits from using below-ground storage chambers (Stratus Consulting, 2009). These benefits accrue to and are seen as valuable by the people of Philadelphia. There is, however, a marked contrast between the situation in Philadelphia and the equivalent jurisdictions and responsibilities in England and Wales.

There are also issues as to who benefits and who pays for the individual benefits, many of which are specific to context or the case under consideration. In England, the water and sewerage companies, alongside local authorities and the Environment Agency, have drainage responsibilities. Bringing these together in a way that maximises opportunities (e.g. 21st Century Drainage Programme (Water UK, 2016)) is not an easy task. Each stakeholder group has specific statutory duties and is constrained as to how these can be fulfilled. Certain stakeholder groups often fail to see the connections between one set of duties and another, such as the revised health duties placed on local authorities by the Department of Health (DoH, 2011). Despite clear evidence of BGI bringing major health benefits (Kirby and Russell, 2015) (see Section 3.3), few local authorities or health authorities engage in what is seen as the 'drainage' domain to take advantage of the wider benefits on offer.
A further case study considered the wider benefits SuDS uptake could bring to London. Ossa-Moreno et al. (2017) used Best to demonstrate the significant added benefits to both householders and the local authority. There are a number of other beneficiaries, including major infrastructure providers for electricity, roads and the London Underground, although the benefits to wider society were rated low, at only around $1 \%$. However, these results only reflect the SuDS options investigated. Alternatives would accrue other benefits and include other beneficiaries.

There is increasing interest in urban planning for and with multi-functional infrastructure and the role that SuDS can play in facilitating this (e.g. Hansen and Pauliet, 2014). SuDS need to play a major part in realising what can be achieved through these urban planning processes, especially in local area development plans. In England, the primary planning instrument is the National Planning Policy Framework (DCLG, 2012), which mentions SuDS as part of the objective to ensure 'sustainable development'. Lack of commencement of Schedule 3 of the Flood \& Water Management Act 2010, which relates to $\mathrm{SuDS}$, is a significant limitation in the promotion of the use of SuDS. Because of this, the Chartered Institution of Water and Environmental Management concluded that policy constraints are the major block to SuDS uptake in England through weak planning policy, resource limitations of local authorities, a lack of clarity regarding adoption and weak standards leading to poor quality schemes (Ciwem, 2017).

In contrast to the situation in England, in Wales, the Wellbeing of Future Generations (Wales) Act 2015 (Welsh Government, 2015) is intended to make the public bodies listed in the Act think more about the long term, work better with people and communities and each other and to take a more joined-up approach. In delivery, public service boards have been established who will have significant opportunities to take an overview of SuDS and their associated benefits, ensuring that these are secured to the maximum benefit of the people of Wales.

\section{Conclusions}

The development of tools such as Best has provided the means to estimate the financial benefits provided from the use of SuDS. The case studies presented in this paper show how Best can help to provide insights into the overall and individual benefits from SuDS, often as a by-product of the primary requirements of the decision maker. In two of the three case studies presented, the main by-product is elevated property prices, despite other benefits being aimed for as the primary objective. As such benefits accrue to property owners and developers, this raises the question as to who should pay for such benefits.

The case studies show that there is a need for planners of SuDS to look beyond BaU analysis where today's situation is 
used for design, together with uplifts to rainfall and urbanisation, to include scenario planning to test option robustness and also evaluate the way in which benefits may change over the lifetime of a scheme. This ensures that the expected service can continue to be provided whatever happens in the future.

The other main benefit found in two of the case studies is the wider value of green SuDS to human health (Section 3.3). Although health is a major aim of many of the institutional players engaged with water and urban place-making, it is still rare to find cases where these players are actively investing in making better places to live, which includes SuDS, thus improving health via changing living conditions instead of dealing only with the symptoms of illness (Kirby and Russell, 2015).

Concerted effort will be required from all parties with an interest in water, drainage and other domains that benefit from SuDS in order to take advantage of the valued benefits SuDS can provide. In many countries, the funders and beneficiaries are clear, but less so in others. Matching opportunities to infrastructure providers is a great challenge and probably the greatest uncertainty for the security of future service provision (Lawson et al., 2015). It is time to raise questions about the way in which our society structures the provision of essential services around water systems.

If the current market failure from not utilising SuDS (Ciwem, 2017 ) is to be addressed there needs to be greater understanding among the whole range of infrastructure and service providers of the opportunities SuDS can provide. This requires education, leadership from professional institutions (e.g. Ciwem, 2017) and a willingness to engage with property owners, dwellers and all strata of society to move on from drainage as 'a problem' to 'it's not drainage - it's an opportunity'.

\section{Acknowledgements}

The authors thank Yorkshire Water, Northumbrian Water and the City of Dordrecht for permission to use the case studies as illustrative examples. These are not the finalised outcomes of these studies and do not necessarily define the ultimate decisions made. The views expressed by the authors in this paper are their own and do not necessarily represent the views of their organisations.

\section{REFERENCES}

Abson DJ, Fischer J, Leventon J et al. (2016) Leverage points for sustainability transformation. Ambio 46(1): 30-39.

Allen CR, Birge HE, Bartelt-Hunt S et al. (2016) Avoiding a decline: fostering resilience and sustainability in midsize cities. Sustainability 8(9): 844.

Brisley R, Wylde R, Lamb R et al. (2015) Techniques for valuing adaptive capacity in flood risk management. Proceedings of the Institution of Civil Engineers - Water Management 169(2): 75-84, http:/l dx.doi.org/10.1680/wama.14.00070.
Casal-Campos A, Fu G, Butler D and Moore A (2015) An integrated environmental assessment of green and gray infrastructure strategies for robust decision making. Environmental Science and Technology 49(14): 8307-8314.

Ciria (Construction Industry Research Information Association) (2013) Ciria Research Project RP993 Demonstrating the Multiple Benefits of SuDS - A Business Case (Phase 2) Literature Review (October). Ciria, London, UK. See http://www.susdrain. org/resources/best.html (accessed 09/08/2017).

Ciria (2015) Demonstrating the Multiple Benefits of SuDS - A Business Case - Review of Sources. Ciria, London, UK. See http://www. susdrain.org/resources/best.html (accessed 09/08/2017).

Ciria (2016) BeST (Benefits of SuDs Tool) Technical Guidance Release Version 3. Ciria, London, UK. W045c RP993. See http://www. susdrain.org/resources/best.html (accessed 09/08/2017).

Ciria (2017) Demonstrating the Multiple Benefits of SuDS Case Studies. Ciria, London, UK. See http://www.susdrain. org/resources/best.html (accessed 09/08/2017).

Ciwem (Chartered Institution of Water and Environmental Management) (2017) A Place for SuDS? Ciwem, London, UK.

CNT (Center for Neighborhood Technology) (2010) The Value of Green Infrastructure; a Guide to Recognizing its Economic, Environmental and Social Benefits. CNT, Chicago, IL, USA. See http://www.cnt. org/repository/gi-values-guide.pdf (accessed 09/08/2017).

DCLG (Department of Communities and Local Government) (2012) National Planning Policy Framework. DCLG, London, UK.

Defra (Department for Environment, Food and Rural Affairs) (2011) An Introductory Guide to Valuing Ecosystem Services. Defra, London, UK. See https://www.gov.uk/government/publications/ an-introductory-guide-to-valuing-ecosystem-services (accessed 29/04/2016).

DoH (Department of Health) (2011) Public Health in Local Government. DoH, London, UK. Gateway Reference 16747.

Eckart J, Sieker H, Vairavamoorthy K and Alsharif K (2012) Flexible design of urban drainage systems: demand led research for Hamburg-Wilhelmsburg. Reviews in Environmental Science and Bio/Technology 11(1): 5-10.

EEA (European Environment Agency) (2016). Circular Economy in Europe - Developing the Knowledge Base. EEA, Copenhagen, Denmark. Report No 2/2016, ISSN 1977-8449.

Eftec (Economics for the Environment Consultancy) (2009) Valuing Environmental Impacts: Practical Guidelines for the Use of Value Transfer in Policy and Project Appraisal. Eftec, London, UK.

Ellis JB and Lundy L (2016) Implementing sustainable drainage systems for urban surface water management within the regulatory framework in England and Wales. Journal of Environmental Management 183(Pt 3): 630-633.

Esquivel Gómez N (2016) Multi-benefit Assessment of Blue-Green Infrastructure Using Multiple Tools: A Small Scale Approach. Case Study: Elwood, Port Phillip, Australia. MSc thesis, Unesco-IHE, Delft, Netherlands, WSE-FRM, 16.09.

Fletcher TD, Shuster W, Hunt WF et al. (2015) SUDS, LID, BMPs, WSUD and more - the evolution and application of terminology surrounding urban drainage. Urban Water Journal 12(7): 525-542.

Flood and Water Management Act 2010 Elizabeth II. Chapter 29 Her Majesty's Stationery Office, London, UK.

Hansen R and Pauliet S (2014) From multifunctionality to multiple ecosystem services? A conceptual framework for multifunctionality in green infrastructure planning for urban areas. Ambio 43(4): $516-529$.

Hoang L, Fenner RA and Skenderian M (2016) A conceptual approach for evaluating the multiple benefits of urban flood management practices. Journal of Flood Risk Management, http://dx.doi.org/ $10.1111 /$ jfr3.12267. 
Jayasooriya VM and Ng AWM (2014) Tools for modeling of stormwater management and economics of green infrastructure practices: a review. Water, Air, \& Soil Pollution 225: 2055, http://dx.doi.org/ 10.1007/s11270-014-2055-1.

Kirby V and Russell S (2015) Cities, Green Infrastructure and Health. A Paper for the Foresight Future of Cities Project. Landscape Institute, London, UK. See https://www.gov.uk/government/ uploads/system/uploads/attachment_data/file/444322/future-citiesgreen-infrastructure-health.pdf (accessed 09/08/2017).

Lawson E, Thorne C, Wright $\mathrm{N}$ et al. (2015) Evaluating the multiple benefits of a blue-green vision for urban surface water management. Proceedings of Ciwem UDG Autumn Conference \& Exhibition, Chester, UK.

Maier HR, Guillaume JHA, van Delden H et al. (2016) An uncertain future, deep uncertainty, scenarios, robustness and adaptation: how do they fit together? Environmental Modelling and Software 81: 154-164, https://doi.org/10.1016/j.envsoft.2016.03.014.

Obst C, Hein L and Edens B (2016) National accounting and the valuation of ecosystem assets and their services. Environmental and Resource Economics 64(1): 1-23.

Ossa-Moreno J, Smith KM and Mijic A (2017) Economic analysis of wider benefits to facilitate SuDS uptake in London, UK. Sustainable Cities and Society 28: 411-419, https://doi.org/10.1016/ j.scs.2016.10.002.

Social Value UK (2012) A Guide to Social Return on Investment. Social Value UK, Liverpool, UK. See http://socialvalueuk. org/what-is-sroi/the-sroi-guide (accessed 28/04/2016).

Stratus Consulting (2009) A Triple Bottom Line Assessment of Traditional and GI Options for Controlling CSO Events in Philadelphia Watersheds. Office of Watersheds, City of Philadelphia Water Department, Philadelphia, PA, USA.
Sukhdev P, Wittmer H, Schröter-Schlaack C et al. (2010) The Economics of Ecosystems and Biodiversity: Mainstreaming the Economics of Nature: A Synthesis of the Approach, Conclusions and Recommendations of TEEB. Progress Press, Valletta, Malta. See http://www.teebweb.org/our-publications/teeb-study-reports/ synthesis-report/ (accessed 09/08/2017).

UKCIP (UK Climate Impacts Programme) (2000) Socio-economic Scenarios for Climate Change Impact Assessment: a Guide to their Use in the UK Climate Impacts Programme. UKCIP, Oxford, UK. See http://www.ukcip.org.uk/wp-content/PDFs/socioeconomic_tec. pdf (accessed 28/04/2016).

Van Dijk R, Jansen L, Merkx L et al. (2013) Van TEEB-stad naar TEEBstad tool: Inzicht in de waarde van groen in de stad. Elba Media, Amersfoort, Netherlands. See http://www.platform31. $\mathrm{nl} /$ publicaties/van-teeb-stad-naar-teeb-stad-tool\# (accessed 09/08/2017) (in Dutch).

Water UK (2016) 21st Century Drainage Programme. Water UK, London, UK. See http://www.water.org.uk/policy/improvingresilience/21st-century-drainage (accessed 09/08/2017).

Welsh Government (2015) The Well-being of Future Generations (Wales) Act 2015. Welsh Government, Cardiff, Wales.

WHO (World Health Organization) (2016) Urban Green Spaces and Health. Regional Office for Europe, Copenhagen, Denmark.

Woods Ballard B, Wilson S, Udale-Clarke H et al. (2015) The SuDS Manual. Ciria, London, UK, C753. See http://www.ciria.org/ Memberships/The_SuDs_Manual_C753_Chapters.aspx (accessed 09/08/2017)

Zhou Q, Panduro TE, Thorsen BJ and Arnbjerg-Nielsen K (2013) Adaption to extreme rainfall with open urban drainage system: an integrated hydrological cost-benefit analysis. Environmental Management 51(3): 586-601.

\section{How can you contribute?}

To discuss this paper, please email up to 500 words to the editor at journals@ice.org.uk. Your contribution will be forwarded to the author(s) for a reply and, if considered appropriate by the editorial board, it will be published as discussion in a future issue of the journal.

Proceedings journals rely entirely on contributions from the civil engineering profession (and allied disciplines). Information about how to submit your paper online is available at www.icevirtuallibrary.com/page/authors, where you will also find detailed author guidelines. 